\title{
Rozmowa z Dominikiem Pokornowskim, manager PR, Centrum Sztuki Współczesnej „Znaki Czasu“ w Toruniu
}

Rozmowę przeprowadzono w marcu 2013 roku

Barbara Brodzińska-Mirowska. W dyskusji na temat wykorzystania nowych technologii w komunikacji, która trwa od dłuższego czasu, możemy usłyszeć wiele opinii. Niektórzy mówią wręcz o rewolucji. Czy rzeczywiście zmiany, które obserwujemy i badamy, są rewolucyjne?

Dominik Pokornowski: W związku z erą Web 2.0, popularnością blogosfery oraz pojawieniem się social media mamy do czynienia z rewolucją w komunikacji, nie tylko w kontekście biznesu (tj. firm i przedsiębiorstw), ale przede wszystkich instytucji, także tych non profit. Zyskaliśmy nowe narzędzia do komunikowania się i budowania wizerunku. Duże możliwości, jakie dają media społecznościowe, wymagają jednak strategicznego myślenia na każdym poziomie.

\section{B.B.-M. Rozwój blogosfery można uznać, Twoim zdaniem, z prze- jaw tej rewolucji?}

D.P. Nie wolno nie doceniać sukcesu blogosfery, który jest dla mnie rewolucyjny. Wielu blogerów zyskało pozycję o wiele silniejszą niż dziennikarze. Gdybyśmy przyjrzeli się jakimś konkretnym przestrzeniom biznesu, to okaże się, że wpływowy bloger, sprawny w zakresie public relations, odgrywa ważniejszą rolę niż dziennikarz. Czy użytkownicy portali społecznościowych odczuwają pewien przesyt? Chyba tak, jest to głównie związane z nadmiernym nasyceniem portali mechanizmami marketingowymi. Eksperci mówią, że tak naprawdę przyszłość społeczności leży w bardzo wąskim specjalizowaniu się. Może w przyszłości Mark Zuckerberg otworzy kilkanaście Facebooków dla różnych społeczności? Wielkie marki, swoje nowe produkty najpierw dostarczają blogerom, aby $\mathrm{Ci}$ je przetestowali. Dopiero w dalszej kolejności zabiegają o publikacje na temat swoich pro- 
duktów w magazynach, czasopismach i tradycyjnych mediach. Trudno też przeczyć, że współcześnie znakomici dziennikarze są również blogerami. Granica między tymi dwiema rolami powoli zaciera się i może to jest właśnie przejaw rewolucji.

B.B.-M. Zmiany, o których tu rozmawiamy, wpłynęły na sposób zarządzania komunikacją, ale także na konsumentów. Co jest zatem kluczowe w skutecznej komunikacji online, co jest jej niewątpliwą zaletą?

D.P. Podam przykłady tych zmian z perspektywy instytucji kultury. Otóż mamy do czynienia z multikomunikacją. Jak to rozumieć? Użytkownik zadający pytanie, np. na Facebooku, odnośnie do jakiejś wystawy, dostępności i ceny biletu, godziny seansu, otrzymuje odpowiedź tak szybko, jak to tylko możliwe. Co najważniejsze, ta odpowiedź trafia również do całej społeczności, która śledzi profil. Innymi słowy, odpowiedź adresowana do kogoś konkretnego, ale należącego do społeczności jest też odpowiedzią na pytania, które mogły zrodzić się w głowach pozostałych użytkowników. Zgadzam się z opinią, że w komunikacji online kluczowy jest ułatwiony dostęp do informacji. W każdym momencie możemy sprawdzić ceny towarów i usług, ich dostępność, jakość itd. Możemy też sprawdzić, na ile opinie internautów są wiarygodne.

B.B.-M. W kontekście wątków, jakie tu poruszamy, pojawia się jeszcze jedno ważne zagadnienie, mianowicie polityka prywatności. Gdzie leżą granice analiz naszych zachowań w Internecie pod kątem marketingowo-sprzedażowym?

D.P. Polityka prywatności jest przedmiotem dyskusji rządów i Komisji Europejskiej. Wydaje mi się, że to jeden z najpoważniejszych problemów, przed którymi obecnie stoimy. Może dobrze, że te granice i regulacje prawne zostaną ustalone odgórnie? Choć niezadowoleni od razu podniosą krzyk, że to przejaw cenzury gospodarczej.

B.B.-M. Rozwój rynku internetowego będzie rodził nowe pomysł na kontakt z użytkownikiem/klientem. Czy w kolejnych latach narzędzia mobilne, o których w ostatnich miesiącach bardzo dużo się mówi, będą dominowały?

D.P. Reklama, dla której nośnikiem są urządzenia mobilne, to kolejny krzyk mody dla domów mediowych. Jednak w naszych realiach nadal będzie dominować reklama tradycyjna. Popularność smartfonów nie jest jesz- 
cze na tyle duża, żeby robić kampanie wykorzystujące rozszerzoną rzeczywistość. To jest nisza, która nie ma większego znaczenia. Uważam jednak, że na rynku mobilnym dzieje się coś istotnego. Ważna jest komunikacja za pośrednictwem klasycznych serwisów internetowych, które powinny w coraz większym stopniu być przystosowywane do urządzeń mobilnych. Tę kwestię odzwierciedla modne ostatnio pojęcie: Responsive Web Design. Polski Internet rozwija się cały czas, wiele firm nadal nie dysponuje swoimi stronami, w tej grupie są głównie małe i średnie przedsiębiorstwa. Wiele instytucji i firm ma wprawdzie strony internetowe, ale „przedpotopowe”. Jak w tej sytuacji mówić o mobilnych rozwiązaniach? Reasumując, życzyłbym sobie i wszystkim, aby to właśnie ten trend - mobilne serwisy www - był dominujący. Mogę wskazać na pojedyncze przykłady, w których rozwiązania komunikacji online są rewelacyjne. Niestety większość instytucji wypada niekorzystnie pod tym względem. Teraz trwa „szturm” na aplikacje, a czasami okazuje się, że ona po prostu nie jest organizacji w ogóle potrzebna. Przeważnie ważniejszy jest po prostu dobry serwis www.

B.B.-M. Internet tworzy specyficzną przestrzeń komunikacyjną. Jedną z jej cech jest nieodporność na kryzys. Można odnieść wrażenie, że ten obszar to prawdziwa pięta achillesowa polskich instytucji i firm.

D.P. Istotnie, w mediach społecznościowych dochodzi do kryzysów i to jest jedno z głównych zagrożeń. Uważam jednak, że jeśli kryzys pojawi się w rzeczywistości poza Internetem, to i tak pierwsza reakcja na niego powinna nastąpić właśnie w mediach społecznościowych. Jeśli sami nie postawiamy pierwszego kroku w social media, to społeczność zrobi to za nas, kryzys się spotęguje. W zarządzaniu kryzysem istotna jest dzisiaj rola komunikacji wyciszającej, prowadzonej w mediach społecznościowych.

B.B.-M. Zmiany technologiczne i rozwój Internetu rodzą wiele wątpliwości, problemów i wyzwań, ale w sposób znacząco modyfikują też rynek pracy. Kompetencje związane z komunikacją online bardzo zyskały na znaczeniu. Jakie cechy i umiejętności są kluczowe, jeśli ktoś chce zawodowo zajmować się tego typu branżą?

D.P. Możemy trafić do dużej firmy, gdzie tematy związane z komunikacją internetową będą podzielone, gdzie funkcjonuje dział strategicznie zajmujący się komunikacją social media i marketingiem. Najczęściej jednak czeka nas kariera jednoosobowego "superteamu” do komunikacji internetowej. Mógłbym wyliczyć cały zestaw umiejętności, którymi winien legity- 
mować się specjalista ds. komunikacji online. Warto na pewno legitymować się podstawami programowania - HTML, programowanie PHP. Wypada znać choć trochę Photoshopa, aby móc szybko edytować grafikę. Należy znać podstawowe mechanizmy w reklamie, zatem przydatna jest wiedza z zakresu psychologii i socjologii. Nieodzowna jest umiejętność pisania tekstów na potrzeby Internetu. Warto ćwiczyć warsztat, bo jest to, jak wiemy, zupełnie inne, specyficzne pisanie. Teksty w Internecie muszą być oczywiście poprawne, zgodne z regułami i netykietą. Często pożądani są pracownicy o rozwiniętych kompetencjach społecznych, otwarci na nowinki i nastawieni na śledzenie tego wszystkiego, co się wokół nas zmienia. Ważna rzecz na koniec, kluczowa - umiejętność wyszukiwania informacji.

\section{Bardzo dziękuję za rozmowę}

